\title{
DIE GEBOORTEDATUM VAN CHRISTUS AS 'N HISTORIESE PROBLEEM
}

\author{
F.P. Retief, ${ }^{1}$ J.F.G. Cilliers, ${ }^{2}$ M.J.H. Hoffman ${ }^{3}$
}

\section{OPSOMMING}

Pogings in die verlede om die geboortedatum van Christus vas te stel, het daartoe gelei dat datums so vroeg as 20 v.C. maar ook so laat as 2 n.C. voorgestel is. In hierdie artikel word die beperkte primêre historiese bronne noukeurig ontleed en kontemporêre interpretasies daarvan krities in oënskou geneem. Sterrekundige aspekte rakende die sogenaamde "ster van Betlehem" word ondersoek ten einde vas te stel in watter mate dit kan bydra tot 'n akkurater vasstelling van Christus se geboortedatum. Hierdie ondersoek lei tot die gevolgtrekking dat die geboortedatum van Christus in 5 v.C. of 6 v.C. (tussen Maart en November) vasgestel moet word.

\section{ABSTRACT \\ THE DATE OF CHRIST'S BIRTH AS A HISTORICAL PROBLEM}

In the past attempts to establish the date of birth of Jesus have led to proposed dates as early as $20 \mathrm{BC}$ but also as late as $2 \mathrm{AD}$. In this article the limited primary historical sources are carefully examined and contemporary interpretations of these sources are critically reviewed. Astronomical information concerning the so-called "star of Bethlehem" is examined to determine to what extent it can contribute to a more accurate pinpointing of the date of birth. This examination leads to the conclusion that the date of birth of Jesus should be placed in $5 \mathrm{BC}$ or $6 \mathrm{BC}$ (between March and November).

1 Prof. F.P. Retief, Navorsingsgenoot, Departement Engels en Klassieke Tale, Fakulteit Geesteswetenskappe, Universiteit van die Vrystaat, Posbus 339, Bloemfontein 9300. E-pos: fpretief@shisas.com.

2 Dr. J.F.G. Cilliers, Senior Lektor, Departemente Engels en Klassieke Tale, Fakulteit Geesteswetenskappe, Universiteit van die Vrystaat, Posbus 339, Bloemfontein 9300. E-pos: jcillier@mweb.co.za.

3 Prof. M.J.H. Hoffman, Senior Lektor, Departement Fisika, Fakulteit Natuurwetenskappe, Universiteit van die Vrystaat, Posbus 339, Bloemfontein 9300. E-pos: hofmamj@sci.uovs.ac.za. 
Die geboorte van Christus as Messias, 'n sentrale gebeurtenis in die ontstaan van die Christelike geloof, is herhaaldelik in die Ou Testament voorspel — vir die eerste keer deur die Moabitiese profeet, Bileam (Num. 24:17). Die geboorte as 'n historiese gebeurtenis waaroor daar beperkte primêre inligtingsbronne bestaan, is op wetenskaplike vlak reeds ekstensief beredeneer (Mann 1965:46-58; Hoehner 1977:11-28; Hughes 1979). In hierdie studie word bestaande sienings op 'n bevatlike wyse in oorsig geneem met oorweging ook van sterrekundige verskynsels rondom die sogenaamde "ster van Betlehem" om sodoende tot groter sekerheid omtrent die geboortejaar van Christus te kom.

\section{1. 'N OORSIG VAN DIE GEBOORTEVERHAAL}

\subsection{Antieke bronne}

Die verhaal van Christus se geboorte berus byna uitsluitlik op NuweTestamentiese gegewens uit die eerste twee hoofstukke van Matteus en Lukas. In hierdie ondersoek word die Evangelies as historiese bronne aanvaar met die besef dat hulle primêr geskryf is om Christus wat in die werklike geskiedenis as Seun van God geleef, gesterf en opgestaan het, te verkondig, en nie om in die eerste plek geskiedskrywing te wees nie (Du Toit et al. 1980:6-8; Bruce 1982:159 n.1). Ons aanvaar die historisiteit van Christus se geboorte as 'n gegewe maar is bewus daarvan dat sommige Bybelverklaarders die geboortegebeurtenis grotendeels allegories-metafories wil sien. Hulle wys dan onder andere op ooreenkomste met ander Mediterreense en Oosterse verhale soos byvoorbeeld die beweerde maagdelike geboortes of gode-vaderskap in die gevalle van Romulus, Sargon, Kores, Plato en Alexander die Grote. Hierdie navorsers wys ook op sterre wat as voorbodes van die geboorte of sterwe van bekendes soos Mithridates en Alexander Severus beskou is (Mann 1965:48). In hierdie ondersoek word sodanige allegories-metafories verklaring van die oorleweringe rondom Christus se geboorte egter nie aanvaar nie.

Onder die apokriewe geskrifte rakende die Nuwe Testament bevat die Oer-evangelies van Jakobus en Maria (albei uit die $2^{\text {de }}$ eeu n.C.) en die Geskiedenis van Josef die Timmerman (geskryf teen omstreeks 400 n.C.) wel fragmente oor die geboorte van Christus, maar dit word nie in 
hierdie studie behandel nie omdat dit geen lig op spesifiek die geboortedatum van Christus werp nie (Muller 1976:vii-xix).

Wat Joodse bronne betref, vermeld Josefus (37-c.95) nie die geboorte van Christus nie. Ongeveer 70 jaar ná Christus se dood het kritiese opmerkings oor Christus wel in die Talmud begin verskyn waarin onder andere beweer is dat Hy die buite-egtelike kind van 'n egbreekster, Miriam ('n haarkapster), by 'n Romeinse soldaat, Pandera, was. Hierdie goed nagevorste maar aanvegbare bewerings omtrent Christus werp egter geen lig op Christus se geboortedatum nie (Hoffmann 1984: 36-53; Keller 1956:325-326).

In die geskrifte van die profane Latynse skrywers, Tacitus (c.56c.117 n.C.) en Suetonius (c.70-c.130) is daar terloopse verwysings na Christus maar geen inligting omtrent sy geboorte nie.

Enkele vroeg-Christelike Griekse en Latynse skrywers noem wel geboortedatums van Christus. Volgens Eusebius (c.260-c.340 n.C.) se getuienis moet Christus se geboortedatum op 2 v.C. vasgestel word (Ekklêsiastikêe Historia 5.2-3), 'n datum wat hy in sy Chronikoi (red. Schoene 1967:144) herhaal. Hierdie datum stem ooreen met die datum wat Clemens van Alexandrië (c.150-c.216) vroeër reeds in sy Stromata 1.21 as die geboortedatum van Christus noem. Dieselfde datum word deur die latere Christelike skrywers, Epifanius van Salamis (c.315c. 403 n.C.) in sy Haereses 51.22 genoem, asook deur Orosius (fl. 414 n.C.) in sy Historiae adversus Paganos 1.1. Albei laasgenoemde skrywers is waarskynlik deur Eusebius beïnvloed. Irenaeus (c.130-c.200 n.C.) het egter 3 v.C. as die geboortejaar van Christus aangedui (Adversus Haereses 3.25) en hierdie datum word ook deur Tertullianus (c.155c.240) in sy Adversus Judaeos 8 aanvaar. Hierdie daterings van Christus se geboortejaar deur die vroeg-Christelike skrywers is egter almal problematies soos hieronder sal blyk (Schaff 1979:88 n.1).

\subsection{Samevatting van gebeure (Matteus 1 en 2, Lukas 1 en 2)}

Christus, maagdelik verwek deur die Heilige Gees, is vir Maria en haar man Josef in Betlehem gebore. Hulle het daarheen gegaan omdat Josef na sy familiedorp moes reis vir 'n sensus wat deur keiser Augustus uitgeskryf is in die tyd van Sirenius (Quirinius), goewerneur van Sirië. Die pasgebore baba is deur 'n groepie skaapwagters vereer wat deur 
'n engel oor die Messiaanse geboorte ingelig is terwyl hulle in die veld oor hul skape gewaak het. Hierna is die kind ook deur wyses uit die Ooste besoek wat op sterkte van 'n ster wat hulle waargeneem het, vermoed het dat 'n besondere koning vir die Jode gebore is. Die wyses het op pad by koning Herodes die Grote aangedoen om te verneem waar die nuwe koning gebore sou word waarop hy deur die Joodse skrifgeleerdes ingelig is dat Miga die Messias se geboorte in Betlehem voorspel het. Toe die wyses op pad terug nie weer by Herodes aangedoen het om oor die kindjie te rapporteer nie, het hy alle seuntjies onder twee jaar in Betlehem en omstreke laat doodmaak. Deur die Here gewaarsku, het Josef en sy familie egter betyds na Egipte gevlug vanwaar hulle eers na die dood van Herodes teruggekeer het. Nadat hulle in 'n droom gewaarsku is teen Argelaus, die nuwe koning van Judea, het hulle toe nie na Betlehem nie, maar na Nasaret in Galilea gegaan.

Die elemente uit hierdie verhaal wat mag bydra tot die datering van Christus se geboorte sluit onder andere die volgende in: die sensus van Augustus en die goewerneurskap van Sirenius, die dood van Herodes die Grote, die ster wat deur die wyses uit die Ooste waargeneem is (die "ster van Betlehem"), die kindermoord van Betlehem, die verhaal van die skaapwagters en die vlug na Egipte. Vervolgens word hierdie verhaalelemente en hul moontlike relevansie vir die vasstelling van Christus se geboortedatum bespreek.

\section{TERSAAKLIKE ELEMENTE UIT DIE VERHAAL}

\subsection{Die sensus en Sirenius}

Christus is gebore tydens die heerskappy van Augustus, wat van 28 v.C. tot 14 n.C. keiser was, en volgens Lukas 2:1 het die geboorte saamgeval met 'n sensusopname wat dwarsdeur die keiserryk gehou is. Volgens Lukas was Sirenius toe goewerneur van Sirië. Hierdie stelling van Lukas is die grootste probleem in verband met die vasstelling van Christus se geboortejaar omdat dit uit nie-Bybelse bronne bekend is dat Sirenius eers in 6 n.C. goewerneur van Sirië geword het toe Herodes alreeds geruime tyd oorlede was. In die jongste tyd het R. Carrier (2001: 1-71) die hele probleem rondom die goewerneurskap van Sirenius grondig ondersoek deur haas alle literêre en epigrafiese getuienis kri- 
ties in oënskou te neem. Augustus het verskeie algemene sensusse uitgeskryf, onder andere in 28 v.C., 19/18 v.C., 8 v.C., 4 n.C. en 14 n.C. (Turner 1965:60-65). Veral vir belastingdoeleindes is plaaslike sensusse ook periodiek in dele van die Ryk gehou. So was daar byvoorbeeld tydens die termyn van die Siriese goewerneur, Saturninus (9-6 v.C.), 'n sensus in Palestina en weer in 6 n.C. onder Sirenius ter afbakening van die provinsie Judea (Hughes 1979:51-52). Alhoewel dit ongewoon sou gewees het vir die keiser om 'n plaaslike sensus binne Herodes se semi-outonome koninkryk te hou, meen Hoehner (1977: 17) dat dit tydens 5-4 v.C. dalk wel kon gebeur het omdat Herodes toe siek en in onguns by die keiser was en omdat Augustus dalk 'n eie opname van die streek verlang het. Hiervoor is daar egter geen verdere getuienis nie. Voorts het die Romeinse reg nie vereis dat gewone sensusse in individue se familiesetels opgeneem moes word nie, maar waar 'n bevolkingsopname vir belastingdoeleindes gehou is, moes die mans wel registreer op die plek waar hul eiendom besit het (Hoehner 1977:15-16).

Sirenius was, soos vermeld, goewerneur van Sirië in 6 en 7 n.C. en het in dié tyd 'n plaaslike sensus gereël wat aanleiding gegee het tot 'n opstand onder die Jode. Die name van alle Siriese goewerneurs tussen 12 v.C. en 7 n.C. is aan ons bekend behalwe vir die tydvak 31 v.C. (Hughes 1979:51). Alhoewel Sirenius as militêre bevelvoerder voor 6 v.C. in Palestina opgetree het, was hy volgens alle inligting net een maal goewerneur van Sirië (Carrier 2001:12-29; Turner 1965: 61-62; Hughes 1979:50-51; Hoehner 1977:18-23).

\section{DOOD VAN HERODES DIE GROTE}

Herodes se dood is 'n belangrike datum omdat Christus tydens sy heerskappy en oënskynlik kort voor sy dood gebore is. Dit word vandag algemeen aanvaar dat Herodes in 4 v.C. gesterf het (Hoehner 1980: 10 n.5; Hughes 1979:55-58; Retief \& Cilliers 2003:300-303). Josefus (Antiquitates Judaicae 17, 155-167, 213) het aangeteken dat daar 'n maansverduistering 'n week of twee voor Herodes se dood was. Daardie datum kan wetenskaplik vasgestel word as die nag van 13 op 14 Maart 4 v.C. om 01h28. Dit was 'n 40\%-maansverduistering (Hughes 1979:54). Josefus (Antiquitates Judaicae 17, 213-218) vermeld voorts dat Herodes gesterf het voor die Paasfees van daardie jaar wat op 11 
April gevier is (Hughes 1977:13). Hy moes dus reeds teen einde Maart of begin April 4 v.C. gesterf het. Onlangse bespiegeling dat hy eers in 1 v.C. gesterf het, is onder andere gebaseer op berekeninge rondom 'n ander maansverduistering wat in daardie jaar plaasgevind het, maar word nie algemeen aanvaar nie (Hughes 1979:57-58, Carroll 2000:13).

In die lig van bogenoemde getuienis moet Christus se geboortedatum dus voor April 4 v.C. geplaas word.

\section{WYSE MANNE UIT DIE OOSTE EN DIE STER}

\subsection{Die wyse manne (magoi)}

Daar is 'n wyd-aanvaarde siening dat die wyse manne uit die Ooste (magoi in Grieks) waarskynlik sterrekundiges uit Persië, Mesopotamië of selfs Arabië was en wat dalk aan 'n bepaalde priesterorde gekoppel was (Hughes 1979:30-33; Ellis 1990:722-723). 'n Uitgebreide mitologie het met verloop van tyd om hulle ontwikkel waarin die wyses later as konings voorgestel is, hul getal op drie gestel is en selfs name aan hul toegeken is. In die vroeë kerk was daar ook denkrigtings wat hulle aan bose praktyke en towerkuns gekoppel het - magoi is die oorsprong van "magies" (magic) en "magiër" (magus/magi, magician) (Ellis 1990:722). Herodotus $(1,101,132)$ het in die $5^{\text {de }}$ eeu v.C. reeds geskryf van 'n priesterlike kaste van besondere magoi in Medië en oud-Persië met besondere vermoëns om onder andere drome te interpreteer. Hulle was veral Zoroastriese priesters met groot invloed op regeringsvlak en was waarskynlik die towenaars en wyses waarna in die boek Daniël verwys word (Dan. 1:19, 20; 2:2; 4:5-7) (Hughes 1979: 31). Daar is voorts 'n sterk vermoede dat daar tydens die Joodse ballingskap in Babilon ( $6^{\text {de }}$ eeu v.C.) wederkerige beïnvloeding tussen die Joodse en Zoroastriese monoteïstiese godsdienste kon gewees het waardeur die Zoroastriese magoi bekend geword het met die Joodse verwagtings van 'n Messias wat gebore moes word (Hughes 1979:34; Carroll 2000:1-16). Die Zoroastriese priesterorde was teen die $1^{\text {ste }}$ eeu nog sterk aktief en volgens Hughes (1979:36-37) was die magoi van noordelike Mesopotamië (Kommagene) bekend vir hul astrologiese voorspellings van koninklike geboortes. Astrologie en astronomie was destyds natuurlik nou verweef sodat in-diepte-studies van sterre, planete en ander hemelliggame vir die magoi belangrik was. 
Indien die wyses uit die Mesopotamiese streek gekom het, sou 'n reis na Jerusalem (te perd of per kameel) waarskynlik ten minste twee weke geduur het. 'n Rustige reis kon 'n maand of langer geneem het (Hughes 1979:38-45). Volgens Matteus 2:1 het die wyses Herodes in Jerusalem besoek. Op die laatste kon dit vroeg Maart 4 v.C. gewees het, want ten tye van die maansverduistering (13/14 Maart) was hy reeds in Jerigo waar hy ook gesterf het (Retief \& Cilliers 2003:300303). Die besoek aan Maria en haar kind word in Matteus 2:11 beskryf waar die Griekse woord vir kind paidion (gewoonlik "n baie jong kind") gebruik word. Matteus 2:1 gee dan die indruk dat die besoek kort na die geboorte plaasgevind het. Mann (1965:46-58) verteenwoordig 'n wye mening waarvolgens hierdie verhaal as 'n gelykenis gesien moet word waarin die nie-Christelike wyses en wysheid (van die Ooste) verneder word voor die Messias en sy Christelike leerstellings (Ellis 1990:722-723).

\subsection{Die "Ster van Betlehem"}

Volgens Matteus 2:2 het die verskyning van die besondere ster in die Ooste die wyse manne daarop bedag gemaak dat 'n koning vir die Jode gebore is of binnekort gebore sou word en dit het hulle op die reis na Palestina geplaas. Sommige Bybelvertalers meen dat die oorspronklike Grieks eintlik daarop dui dat die ster in die Ooste opgekom het eerder as dat dit net daar gesien is (Hughes 1979:25-52). Die ster is 'n tweede keer gesien toe die wyse manne vanaf Jerusalem op pad na Betlehem was (Matt. 2:9, 10).

Die ster kan verklaar word as 'n verdigsel van Matteus, as 'n bonatuurlike verskynsel ('n wonderwerk) of as 'n wetenskaplik verklaarbare sterrekundige verskynsel. Die eerste moontlikheid word nie verder oorweeg nie alhoewel Mann (1965:46-58) 'n saak hiervoor uitmaak. Die moontlikheid van 'n eenmalige wonderwerk soos inderdaad deur vele aanvaar word, word deur Hughes bespreek (1979:195-198). Bohlin (1999:1-7) stel selfs voor dat die ster gesien kan word as 'n manifestasie van die sigbare glorie van God (die sogenaamde Shekinah-verskynsel) soos byvoorbeeld ook vergestalt in die ligkolom wat die Israeliete deur die woestyn gelei het (Ex. 40:38), die brandende braambos (Ex. 9:2, 3) en die vuurgloed wat die berg Sinaï vir die Israeliete bedek het (Ex. 24.17). 
Die moontlikheid dat die "Ster van Betlehem" 'n normale astronomiese verskynsel was, is in die literatuur reeds uitvoerig ondersoek (Hughes 1979). Dis natuurlik ook moontlik dat die sterre- of planeteverskynsel wat vir die wyses uit die Ooste baie beduidend van die geboorte van 'n koningskind was, vir die gewone mens 'n heel onindrukwekkende verskynsel was. Moontlike verklarings wat wel voorgestel is, word nou in kronologiese volgorde kortliks saamgevat.

In 12 v.C. is Halley se komeet deur Chinese waarnemers opgeteken (Keller:1956:324-336).

In 7 v.C. was daar drie maal (in Maart, September en Desember) binne die sterrebeeld van die Visse, simbolies van die Weste en die jong Christelike kerk, konjunksie (nabystand) van die planete Jupiter (koningsplaneet) en Saturnus (beskermer van die Jode) (Hughes 1979: 123-126; Bulmer-Thomas 1992:33, 363).

In 6 v.C. was daar tydens Februarie 'n naby-groepering van die planete Jupiter, Mars en Saturnus, weer in die sterrebeeld van die Visse (Bulmer-Thomas 1992:33, 363). In April het Jupiter as "môrester" in die sterrebeeld van die Ram (tradisioneel geassosieer met die Jode) verrys en is dit by twee geleenthede deur die maan verduister alhoewel dit moontlik vir antieke sterrekundiges nie sigbaar was nie. Gedurende die jaar het die son, Jupiter en Saturnus ook gesamentlik deur die sterrebeeld van die Ram beweeg.

In Maart 5 v.C. het Chinese sterrekundiges in die Steenbok-sterrebeeld 'n helder verskynsel opgemerk wat vir 70 dae sigbaar was en 'n supernova of dalk 'n komeet kon gewees het. Daar is ook getuienis dat Chinese en Koreaanse sterrekundiges in 10 v.C. in die Boötessterrebeeld en weer in April 4 v.C. in die Altair-gebied soortgelyke verskynsels gerapporteer het. Geeneen hiervan is in die Midde-Ooste opgeteken nie, maar mag wel daar waargeneem gewees het (Hughes 1979:120-188).

In 3 v.C. is dubbelplaneetkonjunksies by drie geleenthede in die sterrebeeld van die Kreef opgemerk: Saturnus en Merkurius in Mei, Saturnus en Venus in Junie en Jupiter en Venus in Augustus (Hughes 1979:128-138).

In Junie 2 v.C. het Venus, Jupiter en die volmaan in die sterrebeeld van die Leeu (simbolies van Juda) en naby Regulus (die koning- 
ster) in konjunksie beweeg; in Augustus was daar 'n sametrekking van Mars, Jupiter, Venus en Merkurius in die sterrebeeld van die Leeu. Jupiter en die ster Regulus het in Desember 3 v.C., in Februarie 2 v.C. en weer in Mei 2 v.C. in konjunksie gegaan (Carroll 2000:1-16; Hughes 1979:132-133).

\section{DIE KINDERMOORD}

Die kindermoord in Betlehem en omgewing, soos dit in Matteus 2:16-18 beskryf word en waardeur alle seunskinders onder twee jaar op Herodes se bevel om die lewe gebring is, word nie deur die tydgenootlike historikus, Josefus, vermeld nie. Dit is duidelik dat Makrobius ('n nie-Christen skrywer van die $5^{\text {de }}$ eeu) wel van die gebeurtenis bewus was (Makrobius, Saturnalia 2.4.11).

Hierdie episode word deur sommige as 'n fabel beskou omdat dit volgens hulle onwaarskynlik is dat Josefus so 'n opspraakwekkende insident nie sou beskryf nie (Mann 1965:46-58; Porter 1995:158). Andersyds word egter daarop gewys dat Herodes veral teen die einde van sy lewe so dikwels homself aan menseslagting skuldig gemaak het, dat 'n kindermoord maklik ongerapporteer kon verby gegaan het. Dit is veral waarskynlik as daarop gelet word dat Betlehem ten tye van Christus se geboorte maar 'n bevolking van bykans 'n duisend gehad het sodat daar waarskynlik nie meer as twintig seuns onder twee jaar oud was nie (Hughes 1979:67). Die ouderdomsperk mag daarop berus het dat hy van die wyse manne uit die Ooste afgelei het dat die Christuskind omtrent twee jaar oud moes gewees het. Dit mag egter net sowel 'n lukraak ouderdomsperk gewees het om seker te maak dat die onlangs-gebore Christus omgebring sou word (Hoehner 1977:11-28).

\section{SKAAPWAGTERS}

Volgens Lukas 2:8 was die skaapwagters in die nag in die oop veld by hul vee toe ' $n$ engel hulle oor die geboorte van Christus ingelig het. Keller (1956:335-336) vermeld dat die nagtemperature in die hoogland van Judea na gemiddeld $2,8^{\circ} \mathrm{C}$ in Desember, $1,6^{\circ} \mathrm{C}$ in Januarie en $0,1^{\circ} \mathrm{C}$ in Februarie daal. Ryp en selfs sneeu kom gereeld voor en die reënval is maksimaal in Desember en Januarie. Die klimaatstoestande in die $1^{\text {ste }}$ eeu was waarskynlik vergelykbaar met dié 
van vandag en die Talmud sê dat skaapwagters hul vee tussen November en begin Maart nie in die oop veld laat oornag het nie (Keller 1956:336; Hughes 1979:79-80). Lente was lammertyd en dan het skaapwagters weer hul vee in die oop veld versorg. Alhoewel Hughes (1979:79-80) uitwys dat daar van tyd tot tyd minder strawwe winters mag voorgekom het, lyk dit onwaarskynlik dat skaapwagters waarskynlik nie in die middel van die winter (Desember tot einde Februarie) snags in die veld sou gewees het nie.

\section{VERDERE GEBEURE EN DIE VLUG NA EGIPTE}

Lukas 2:21 vermeld dat Christus agt dae na sy geboorte besny is en sy naam, Jesus, gekry het. Die reinigingsoffer wat volgens Lukas 2: 22-24 in die tempel in Jerusalem gebring is, het volgens gebruik op die $41^{\text {ste }}$ lewensdag plaasgevind, dus ongeveer 6 weke na die geboorte (Hughes 1979:60). Lukas 2:39 vermeld dat Josef ná afhandeling van die wetlike verpligtinge na Nasaret teruggekeer het — die kindermoord en vlug na Egipte word nie genoem nie.

Matteus 2:13-14 vertel dat Josef en sy familie onmiddellik na die vertrek van die wyses uit die Ooste, na Egipte gevlug het in reaksie op 'n hemelse waarskuwing. Hughes (1979:61-64) bereken dat dit moontlik was om binne drie dae te voet van Betlehem na die Egiptiese grens te reis. $\mathrm{Na}$ die dood van Herodes het hulle weer uit Egipte teruggekeer, maar uit vrees vir Argelaus wat sy vader, Herodes, in Judea opgevolg het, het hulle na Nasaret in Galilea en nie na Betlehem in Judea nie, gegaan (Matt. 2:22). Onmiddellik ná sy opvolging en voor die Paasfees op 11 April 4 v.C. was Argelaus verantwoordelik vir die bloedige onderdrukking van Joodse opstande in Jerusalem (Josefus, Antiquitates Judaicae 17, 155-167, 213). Dit is gevolg deur verdere opstande wat deur die Romeinse goewerneur, Varus, hardhandig onderdruk is (Syme 1979:1108-1109). Hierdie omstandighede het waarskynlik veroorsaak dat Josef en sy gesin nie na Judea (Betlehem) teruggekeer het nie. 


\section{ANDER BYBELSE VERWYSINGS NA DIE GEBOORTE}

8.1 Lukas 3:23 vermeld dat Jesus ongeveer 30 jaar oud was toe hy kort na die aanvang van Johannes die Doper se bediening met sy werk begin het. Johannes die Doper het in die $15^{\text {de }}$ jaar van keiser Tiberius se regeringstyd op die toneel verskyn (Luk. 3:1), met ander woorde in 29 n.C. (Hoehner 1977:37). Die omskrywing "ongeveer" is egter te vaag om 'n betekenisvolle geboortedatum van Jesus uit hierdie gegewens te bereken.

8.2 In Johannes 8:57 wys die Jode (met wie Christus in 'n godsdienstige argument betrokke was) daarop dat Hy nog nie 50 jaar oud is nie. Alhoewel sommige meen dat hierdie bewering daarop dui dat Christus tydens sy prediking reeds in sy veertigerjare moes gewees het, is die meerderheidsiening dat die bewering nie so letterlik opgeneem moet word nie en slegs daarop gedui het dat die Jode hom as relatief jonk beskou het (Hoehner 1977:43-44).

8.3 Volgens Lukas 1:36 is dit waarskynlik dat Jesus ongeveer ses maande jonger as Johannes die Doper was. Simmons (aangehaal deur Hughes 1979:78) en Carroll (2000:1-16) poog om die geboortemaande van Johannes en Christus uit gegewens in Lukas 1:5 te bereken waarvolgens Sagaria (Johannes se vader) tydens sy priestersampbediening van die engel verneem het dat sy vrou, Elisabet, swanger is. Sagaria was in die Abia-orde, wat volgens 1 Kronieke 24:7-19 die $8^{\text {ste }}$ van 24 priesterordes was (Greijdanus 1941:24-24). Hierdie orde sou dan in die $8^{\text {ste }}$ week van die $1^{\text {ste }}$ helfte van die Joodse jaar (ongeveer Junie) of die $8^{\text {ste }}$ week van die $2^{\text {de }}$ helfte van die Joodse jaar (ongeveer Desember) diens gedoen het. Hiervolgens is Johannes waarskynlik in Maart of September (nege maande later) gebore en Christus in September of Maart van die volgende jaar. Verskille tussen die Joodse maankalender en ons sonkalender veroorsaak dat sulke berekeninge egter net by benadering gemaak kan word.

8.4 Daar is outeurs wat in die profesie van Daniël 9:25 'n voorspelling lees wat aandui presies wanneer die Messias gebore sou word (Carroll 2000:1-16). Die meerderheidsmening is egter dat die teks nie so letterlik verklaar kan word nie (Vosloo et al. 1999: 965, 986). 


\section{BESPREKING}

Matteus en Lukas stel dit albei baie duidelik dat Christus gebore is terwyl Herodes nog geleef het en hierdie feit moet as die belangrikste leidraad in verband met Christus se geboortedatum beskou word. Herodes is egter reeds tussen 12 Maart en 11 April 4 v.C. oorlede en hierdie datum is seker (Hoehner 1980:10 n.5). As 4 v.C. die korrekte datum vir Herodes se dood is, dan kan die daterings deur die nieBybelse Christelike skrywers wat hierbo genoem is, nie korrek wees nie aangesien hul berekenings neerkom op datums na die dood van Herodes.

Eusebius (Ekklêsiastikê Historia 5.2-3) plaas Christus se geboortedatum in die $42^{\text {ste }}$ jaar nadat Augustus die mag oorgeneem het na die dood van sy groot-oom, Julius Caesar, in 44 v.C. en in die $28^{\text {ste }}$ jaar na die dood van Markus Antonius en Cleopatra in 30 v.C. Clemens van Alexandrië (Stromata 1.21) stel Christus se geboortedatum vas op 194 jaar vóór die dood van keiser Commodus in 192 n.C. Waarom hulle op hierdie datums besluit het, is nie bekend nie. As daar volgens die Romeinse gebruik inklusief getel word, bring dit ons by die jaar 2 v.C. uit wat nie korrek kan wees nie omdat Herodes toe al dood was. Eusebius aanvaar verder dat Sirenius in 2 v.C. goewerneur van Sirië was, terwyl dit duidelik is dat hy slegs gedurende 6 en 7 n.C. goewerneur was. Dieselfde besware geld vir die datum 3 v.C. wat deur Tertullianus (Adversus Judaeos 8) en Irenaeus (Adversus Haereses 3.25) voorgestel is. Daar moet in gedagte gehou word dat hierdie vroegChristelike skrywers nog nie die hedendaagse dateringswyse, vóór en ná Christus, geken het nie en dat kronologiese akkuraatheid vir hulle baie moeilik was (Bickerman 1980:9-11).

Omdat Christus tydens die regering van Herodes die Grote gebore is, moes die geboorte voor Maart of April 4 v.C., die aanvaarde sterfdatum van Herodes, plaasgevind het. In die periode tussen Christus se geboorte en Herodes se dood moes minstens 41 dae, tot en met die reinigingsoffer, verloop het. Die besoek van die wyse manne, die kindermoord in Betlehem en die vlug na Egipte moes ook in hierdie tyd plaasgevind het. Die terugkeer het natuurlik na Herodes se dood plaasgevind (Matt. 2:1-18; Luk. 2:21-24). 
Hierbo is reeds geargumenteer dat die geboortedag, soos aan die herders geopenbaar, nie in die middel van die winter geval het nie - dus waarskynlik tussen Maart en November. Al die bovermelde gebeurtenisse kan beswaarlik tussen 'n geboorte in Maart 4 v.C. en Herodes se dood enkele weke later ingepas word wat beteken dat Christus ten vroegste in die herfs of somer van 5 v.C. of selfs 6 v.C. gebore is. Die verhaal in Matteus 1 en 2 skep egter die indruk dat 'n tydsverloop van 3 jaar tussen die geboorte en Herodes se dood, onwaarskynlik lank sou wees, alhoewel dit nie heeltemal onmoontlik is nie. Berekeninge van Simmons (Hughes 1979:78) en ander (Carroll 2000:1-16) suggereer dat Maart of September die waarskynlikste maande van die jaar was waarin die geboorte kon plaasgevind het.

Te oordeel aan Matteus 2:1 en die woord paidion ('n jong kind) wat in Matteus 2:11 gebruik word, het die wyses uit die Ooste Christus waarskynlik kort na sy geboorte besoek. Daar is egter wel Bybelverklaarders wat meen dat die kindjie Jesus toe reeds een of twee jaar oud was (Hoehner 1977:24). Dit sou dan moontlik kon wees dat die wyses se besoek so laat as vroeg in Maart 4 v.C. plaasgevind het, enkele weke voor Herodes se dood (Retief \& Cilliers 2003:300-303). Die kindermoord in Betlehem en vlug na Egipte onmiddellik na hierdie besoek kon ook in Maart 4 v.C. plaasgevind het. Josef en sy familie het vermoedelik kort na die dood van Herodes teruggekeer, moontlik so vroeg as April of Mei 4 v.C. tydens die regering van Argelaus (4 v.C.-6 n.C.). Dit sou beteken dat die verblyf in Egipte moontlik een, dalk twee jaar geduur het maar ook so kort as twee maande kon gewees het.

Bespiegelinge rondom die aard van die "ster van Betlehem" wat die wyses na Palestina gebring het, sluit 'n verskeidenheid natuurlike astronomiese verskynsels in soos hierbo uiteengesit. Halley se komeet (12 v.C.) was te vroeg vir oorweging, en tensy dit aanvaar word dat Herodes in 1 v.C. en nie 4 v.C. nie gesterf het, kan die indrukwekkende verskynsels van 3-1 v.C. ook uitgeskakel word. Die herhalende konjunksies van Jupiter (koningsplaneet) en Saturnus (beskermer van die Jode) binne die sterrebeeld van die Visse (simbool van die vroeë Christendom) in 7 v.C. kon wel vir Mesopotamiese sterrekundiges gedui het op 'n toekomstige koninklike geboorte (Keller 1956:324336). Hulle was immers bekend met die Joodse tradisie (onder andere 
die voorspelling van Numeri 24:17 dat 'n ster uit Juda te voorskyn sou kom as magtige koning). In Januarie 6 v.C. sou die planetegroepering, weer in die Visse-sterrebeeld, sowel as die besondere beweging (en maaneklips) van Jupiter in die sterrebeeld van die Ram (sterrebeeld van die Jodedom), hul vermoedens kon versterk het (Molnar 1997). Die supernova of komeet wat tydens Maart/April 5 v.C. in China vir 70 dae in die Steenbok-sterrebeeld sigbaar was, sou ook deur Midde-Oosterse sterrekundiges gesien kon gewees het, alhoewel die Steenbok in antieke tye nie simbolies was van koninklike gebeure nie. 'n Mens kan dan bespiegel dat van hierdie verskynsels wel die "ster in die Ooste" (Matt. 2:1) was wat die wyses na Jerusalem gebring het. Klaarblyklik kon hierdie verskynsels egter nie 'n spesifieke woning in Betlehem uitwys nie en sou die "ster" van Matteus 2:9, 10 'n bykomstige verskynsel naby die aarde moes gewees het. Benewens 'n eenmalige wonderwerk wat die Shekinah-verskynsel van Bohlin sou insluit (Keller 1956:324-336; Bohlin 1999:1-7), noem Hughes (1979: 168-171) ook die moontlikheid van meteore-storms en gelokaliseerde weerlig, veral weerligballe of selfs sodiakale lig wat in Palestina mag voorkom. Dit is egter ons mening dat ' $n$ wetenskaplike analise van die "ster van Betlehem" beperkte lig op die presiese datering van Christus se geboorte werp. Die teendeel mag selfs waar wees, naamlik dat 'n meer presiese datering van Christus se geboorte lig mag werp op die aard van die "ster van Betlehem" en die wyse waarop die leke gegewens geïnterpreteer het en in die Bybel weergegee het. So 'n vasstelling mag van belang wees vir Skrifuitleg en interpretasie.

Lukas 2:1-2 se stelling oor die sensus wat Josef en Maria na Betlehem gebring het, mag dui op 'n plaaslike belastinggerigte sensus in Palestina wat nie deur antieke geskiedskrywers vermeld is nie (Hughes 1979:48-52). Dit was egter nie 'n algemene sensus wat deur Augustus uitgeskryf is nie (Turner 1965:59-74). Sirenius mag wel in militêre hoedanigheid in 6 en 4 v.C. in Palestina gewees het, maar eers in 6 n.C. goewerneur van Sirië geword het (Turner 1965:62-63; Hughes 1979:51-52; Hoehner 1977:17-23). Die moontlikheid dat Lukas 2:2 verkeerd vertaal is en byvoorbeeld oorspronklik kon gelees het dat die sensus plaasgevind het voordat Sirenius goewerneur van Sirië was, word deur Hoehner (1977:20-22) en veral Carrier (2201:31-33) volledig ondersoek en onwaarskynlik bevind. 
Kersfees op 25 Desember is 'n baie ou tradisie wat deur Hippolutus (165-235) geïnisieer is (Commentarii in Danielem 4.23.3) en vir die eerste keer in 354 onder keiser Justinianus en Pous Damasus as Christus se geboortedag gevier is. Die kerkvader Johannes Chrisostomus het dit in 384 amptelik onderskryf en teen 394 is 25 Desember algemeen deur die Christengemeenskap as Christus se geboortedag aanvaar (Hughes 1979:85-87; Keller 1956:335). Die vasstelling van hierdie datum, in die middel van die winter, het 'n komplekse, onsekere oorsprong wat waarskynlik op mitologiese eerder as historiese oorweginge gebaseer is, alhoewel sommige outeurs dit vandag nog probeer koppel aan geldige historiese argumente (Hoehner 1977:14-25). Waarskynlik het dit ontstaan uit die geleidelike verchristeliking van Romeinse midwinterfeeste soos dié vir die songod, Sol Invictus, of selfs die Saturnalia gedurende 17-25 Desember (Keller 1956:324-336; Hughes 1979:91-92). Met verloop van tyd is ook ander geboortedatums voorgestel en genoteer, byvoorbeeld 6 Januarie, 20 Mei, 21 en 22 Augustus, 20 September en 5 Desember (Hughes 1979:82-92).

Die huidige kalender is in 525 deur die monnik, Dionusius Exiguus, ontwerp toe hy die bestaande Romeinse kalender wat gebaseer was op berekeninge vanaf die dood van keiser Diokletianus, omskep het ná berekeninge vanaf die geboortejaar van Christus wat hy anno domini 1 (AD 1, oftewel, 1 n.C.) genoem het. Dit het ooreengestem met die Varoniaanse jaar, AUC 754, wat bereken is vanaf die stigting van Rome (Hoehner 1977:25-27; Hughes 1979:70-75). Die nuwe kalender het foutiewelik nie 'n jaar 0 ingesluit nie, en het ook vier jaar verloor deurdat Dionusius die jare wat keiser Augustus as Oktavianus regeer het, buite rekening gelaat het. Hierdie, en moontlik andere misrekeninge het veroorsaak dat vroeg reeds besef is dat Christus inderdaad voor 1 n.C. gebore is.

Samevattend kan gesê word. dat die vroeg-Christelike skrywers die geboortedatum van Christus tussen 4 en 1 v.C. gestel het (Hughes 1979:65-84), en vandag verskil navorsers steeds met vasstellings wat wissel van so vroeg as 20 v.C. (Olmstead 1942:23-26) tot so laat as 2 v.C. (Carroll 2000:1-16). Die meerderheidsgroepering val egter binne 'n nou band van 7 tot 4 v.C. (Hoehner 1977:14-25; Hughes 1979:65-84). Hughes se deeglik beredeneerde voorstel van 7 v.C. berus hoofsaaklik op die groter waarde wat hy aan sterrekundige verskynsels 
heg. Die belangrikste aanname waarop hy sy argument grond, kan egter nie bevestig word nie. Hy beweer dat Lukas (2:1-2) eintlik na Saturninus se sensus ( 8 of 7 v.C.) verwys, en dit verkeerdelik in Sirenius se goewerneurskap plaas.

Ons eie voorstel van 5 v.C., dalk 6 v.C. (tussen Maart en November), as die tyd toe Christus gebore is, is gebaseer oorwegend op 'n interpretasie van Matteus en Lukas as geskiedenis. Daar word veel waarde aan die Evangeliste se verwysing na Herodes die Grote geheg omdat sy sterfdatum betreklik akkuraat bereken kan word uit die inligting wat Josefus verskaf. Lukas se verwysing na Sirenius en die sensus lewer egter probleme op omdat hierdie inligting nie volledig deur ander bewaarde getuienis gestaaf kan word nie. Ons het ook tot die gevolgtrekking gekom dat relevante astronomiese verskynsels slegs beperkte lig op die geboortedatum van Christus werp hoofsaaklik omdat hul verskyningsvorme en tyd van verskyning nie op 'n bevredigende wyse met die ander getuienis omtrent die geboortedatum versoen kan word nie. Dit is duidelik dat tensy daar nuwe primêre antieke getuienis wat lig op Christus se geboorte werp, ontdek word, daar beswaarlik tot 'n akkurater vasstelling van die geboortedatum gekom kan word.

Die finale gevolgtrekking waartoe die skrywers kom, word in Bylae 1 grafies voorgestel. 


\section{BIBLIOGRAFIE}

BICKERMAN E J

1980. Chronology of the ancient world. London: Thames and Hudson.

\section{BRUCE F F}

1974. Jesus and Christian origins outside the new Testament. London: Hodder \& Stoughton.

1982. New Testament history. London: Pickering \& Inglis.

\section{BOHLIN R}

1999. The star of Bethlehem. [Aanlyn] Bekom van: http://www.probe.org/does/ starbeth.html.

\section{BULMER-THOMAS I}

1992. Star of Bethlehem. Quarterly Journal of the Royal Astron. Soc. 33: 363.

\section{CARRIER R}

2001. The date of the nativity in Luke. [Aanlyn.] Bekom van: http://www.infidels. org/library/modern/richard_carrier/quirinius.html.

\section{CARROLL S S}

2000. The star of Bethlehem: an astronomical and historical perspective. [Aanlyn.] Bekom van: http://www.sciastro.net/portia/articles/thestar.html.

\section{Clemens Alexandrinus}

Stromata. In: A. Roberts and J. Donaldson (eds.) The ante-Nicene Fathers. Vol 2. (Grand Rapids, Michigan: Wm. B. Eerdmans Publishing Company, 1979), pp. $165-206$

\section{Du TolT A B (red.)}

1980. Handleiding by die Nuwe Testament. Band 4. Die Sinoptiese Evangelies en Handelinge: inleiding en teologie. Pretoria: N.G. Kerkboekhandel.

\section{ELLIS E E}

1990. Magi. In: J.D. Douglas, N. Hillyer \& F. Bruce (eds.), New Bible Dictionary (Leicester: Intervarsity Press, $2^{\text {nd }}$ edition), pp. 722-723.

\section{EUSEBIUS}

Ekklêsiastikê Historiae. In: P. Schaff \& H. Wace (eds.), The ante-Nicene Fathers. Vol. 1. (Grand Rapids, Michigan: Wm. B. Eerdmans Publishing Company, 1979), pp. 82-387.

Chronicorum canonum quae supersunt. Vol. 2. Ed. A. Schoene et al. 1980 (1866). Dublin/Zurich: Weidmann.

\section{GREIJDANUS S}

1941. Korte verklaring van de Heilige Schrift. Het Evangelie naar Lucas. Deel 1. Kampen: Kok NV. 


\section{HeRODOTUS}

Historiae. Translated by A.D. Godley 1946. London: William Heinemann Ltd. The Loeb Classical Library.

\section{HOEHNER H W}

1977. Chronological aspects of the life of Christ. Grand Rapids, Michigan: Zondervan Publishing House.

1980. Herod Antipas: a contemporary of Jesus. Grand Rapids, Michigan: Zondervan Publishing House.

\section{HOFFMANN R J}

1984. Jesus outside the Gospels. New York: Prometheus Books.

\section{Hughes D}

1979. The star of Bethlehem mystery. London: J.M. Dent.

\section{JOSEFUS}

Antiquitates Judaicae. Translated by R. Marcus 1980. Cambridge, Mass.: Harvard University Press. The Loeb Classical Library.

\section{KELLER W}

1956. The Bible as history. London: Hodder and Stoughton.

\section{MAKROBIUS}

Saturnalia. Ed. J. Willis 1963. Leipzig: Teubner.

\section{MANN C S}

1965. The historicity of the birth narratives. In: s.n., Historicity and chronology in the New Testament (London: S.P.C.K., Theological Collections 6), pp. 46-58.

\section{MARTIN E L}

1991. The star of Bethlehem. Portland: ASK Publishing.

\section{MEIER J P}

1991. A marginal Jew: retbinking the historical Jesus. Vol. 1. New York: Doubleday Publ.

\section{MOLNAR M R}

1997. The star of Bethlehem: the legacy of the magi. [Aanlyn.] Bekom van: http://www.eclipse.net./ molnar.

\section{Muller J J}

1976. Nuwe Testamentiese Apokriewe. Pretoria: N.G. Kerk Uitgewers.

\section{Olmstead A T}

1942. The chronology of Jesus' life. Anglican Theology Review 24:23-26.

\section{PORTER J R}

1995. The illustrated guide to the Bible. London: Duncan Baird Publishers.

\section{Retief F P\& Cilliers J F G}

2003. Illness of Herod the Great. S. A. Medical Journal 93(4):300-303. 
SyME R

1979. Varus, P.Q. In: N.G. Hammond \& H.H. Scullard (eds.), The Oxford

Classical Dictionary (Oxford: Clarendon Press, Second edition), pp. 1108-1109.

\section{TERTUllianus}

Adversus Judaeos. In: A. Roberts and J. Donaldson (eds.) The ante-Nicene Fathers. Vol. 3 (Grand Rapids, Michigan: Wm. B. Eerdmans Publishing Company, 1978), pp. 151-173.

\section{TURNER H E W}

1956. The chronological framework of the ministry. In: s.n., Historicity and chronology in the New Testament (London: S.P.C.K., Theological Collections 6), pp. 59-74.

Vosloo W \& VAN Rensburg F J (reds.)

1999. Die Bybellennium. Vereeniging: ChristelikeUitgewersmaatskappy.

Trefwoorde

Jesus Christus

Geboorte

Ster van Bethlehem

Sirenius
Keywords

Jesus Christ

Nativity

Star of Bethlehem

Quirinius 


\section{BYLAE 1: GEBEURE RONDOM DIE GEBOORTE VAN CHRISTUS}

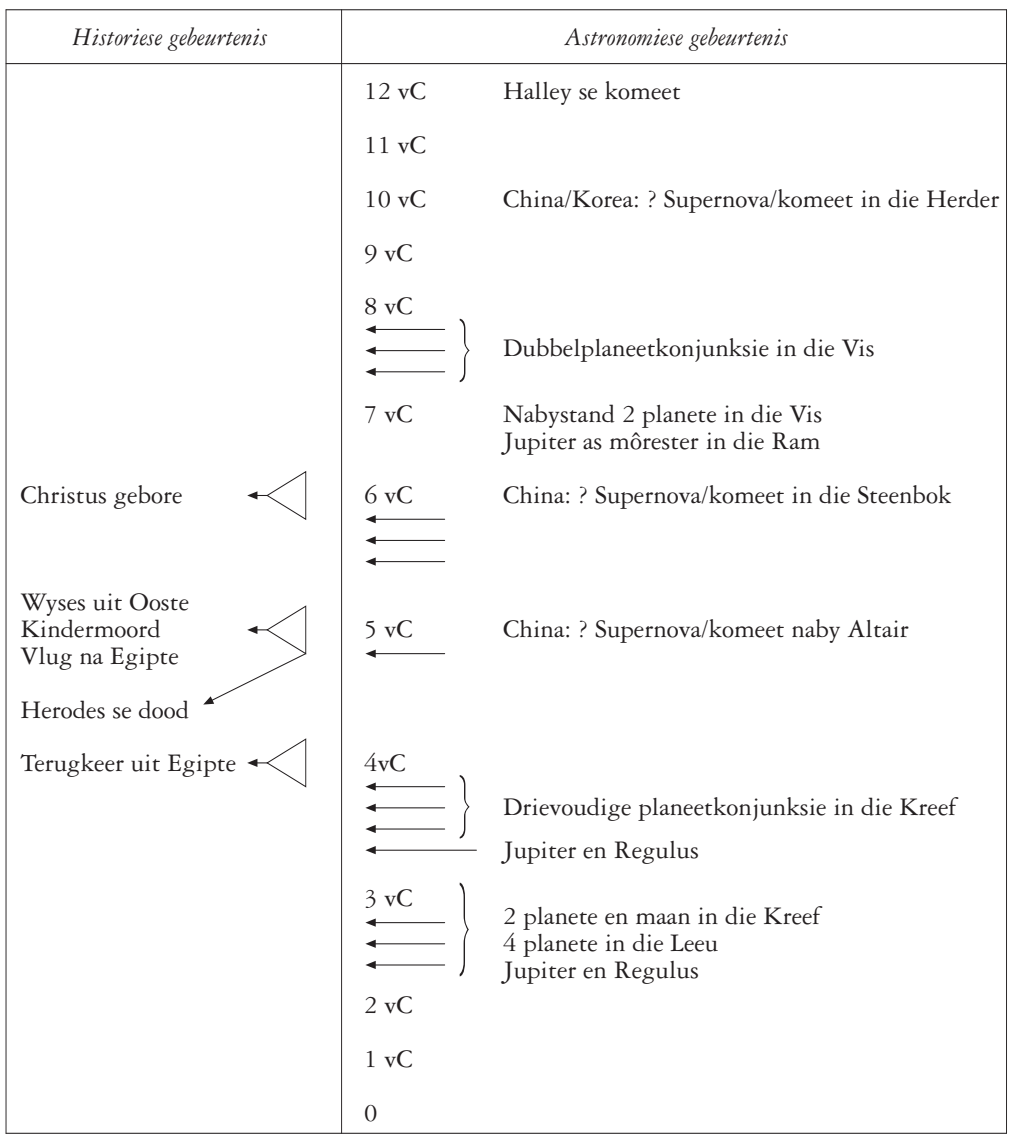

